\title{
LIETUVOS KARIUOMENĖS SKAIČIAI 1920 -1939 M.
}

\author{
Jonas Vaičenonis Vytauto \\ Didžiojo universitetas
}

Ivadas.

\author{
Trumpa Lietuvos Respublikos kariuomenès \\ istoriografijos skaičių apžvalga.
}

Per pastaraji atkurtos Lietuvos Respublikos dešimtmeti gana ryškiai i priekị pasistūmėjo I - osios Lietuvos Respublikos kariuomenès istorijos tyrimai. Šiandien jau turime išleistą ne vieną monografiją ar straipsnių rinkini, kurie yra skirti įvairiausiems kariuomenès gyvenimo ir atskiru jos padaliniu veiklos istorijai. Tačiau juos pavartę, nerasime nè vieno platesnio darbo ar bent jau atskiro skyriaus, kuriame būtu aptarti kariuomenès sudèties skaičiai. Todèl manome, jog yra būtina apžvelgti kariuomenès skaičius, kad turètume dviejų dešimtmečių tokiu duomenu visą spektra. Pateiktus duomenis būtu galima panaudoti ịvairiausiems kariuomenès problemų tyrimams. Šis tyrimas ir pateikta medžiaga palengvintų kiekvieno būsimo kariuomenès istorijos tyrèjo darbą.

I - osios Lietuvos Respublikos kariuomenès studijose jau figūruoja keletas skaičių, kurie tiesiog keliauja iš vieno leidinio i kitą. Tai įvairiausi ir dažnai pabiri duomenys. Iš jų žinome, kad iki 1919 metų kovo 5 dienos, kai buvo paskelbta pirmoji mobilizacija, $\mathfrak{i}$ Lietuvos kariuomenę jau buvo isstoję apie 3000 savanorių ${ }^{1}$ ir kad kovų už Nepriklausomybę metu Lietuvos kariuomenę sudarè apie 25000 karių, o gen.Liucijono Želigovskio vadovaujamų lenkų karinių dalinių puolimo metu paskelbus naują mobilizaciją ir vèl pašaukus savanorius, kariuomenès skaičius išaugo iki 40600 žmonių ${ }^{2}$. Vytenis Statkus savo knygoje pateikia kelis 1920 metu Lietuvos kariuomenès skaičius. Jis nurodo rugpjūčio mėnesio pabaigos kariuome-

\footnotetext{
${ }^{1}$ Statkus V. Lietuvos ginkluotos pajëgos 1918 - 1940 m. Chicago.1986. P.33.; Surgailis G.

Lietuvos kariuomenė 1918 - 1998. Vilnius. 1998. P. 10.

${ }^{2}$ Surgailis G. Lietuvos kariuomenė 1918 - 1998. Vilnius. 1998. P.20.
} 
nès dydi. Tuomet kariuomeneje buvo 608 karininkai ir 16588 kareiviai. Skaičiai pateikiami atskiromis pėstininku divizijomis: I PD - 191 karininkas ir 5130 kareiviu, II PD - 228 karininkai ir 6185 kareiviai, III PD - 189 karininkai ir 5273 kareiviai $^{3}$. Istoriografijoje yra pateikiamas ir tikslus žuvusiujų, mirusių nuo žaizdų, dingusių be žinios sąrašas. Šiais duomenimis, kovose su bolševikais, bermontininkais ir Lenkija žuvo 1444 kariai, šauliai ir partizanai, 2812 mirè nuo ịvairiausių ligų. Tad karas nusinešè 4256 gyvybes. Buvo sužeista 93 karininkai, 2438 kareiviai ir 146 šauliai, iš viso 2766 asmenys. Dingusių be žinios suskaičiuota $226^{4}$. Idomu, kad aukos buvo skaičiuojamos iki 1928 metu.

Taip pat keli $1920 \mathrm{~m}$. bendri Lietuvos kariuomenès skaičiai yra pateikiami Antano Rukšos monografijoje, kur aprašomos lietuvių kovos su lenkais. Baigiamajame žodyje autorius mini, kad 1920 m. Lietuvos kariuomenè buvo pasiekusi 60000 kariu skaičių ${ }^{5}$ Šs skaičius, reikia manyti, paimtas iš Juzefo Smolenskio veikale apie lenkų-lietuvių kovas 1920 metais paminètu duomenu, kur taip pat nurodomas toks pat Lietuvos kariuomenès skaičius ${ }^{6}$. Vienoje iš knygos nuorodų A. Rukša taiso J. Smolenskio klaidingus skaičiavimus ir pateikia dalies Lietuvos kariuomenès, tuo metu buvusios fronte prieš lenkus, skaičius, nurodydamas, kad lietuvių pėstininkų buvo: karininku - 348, eiliniu - 9677; kavalerijos: karininku - apie 10, eiliniu - 400; iš viso tai sudare 358 karininkus ir 10077 kareivius $^{7}$ (viso 10435 kariu).

Aprašydami laikotarpi po Nepriklausomybės kovų iki Lietuvos Respublikos okupacijos, istorikai pateikia dar keletą atskiru kariuomenès dydį nusakančių skaičiu. Gintauto Surgailio duomenimis, 1922 m. sausio 1 d. Lietuvos kariuomeneje tarnavo 52963 kariai, kurie buvo kovinès parengties. Tuo metu kariuomenę sudare 13 pèstininku, 3 kavalerijos, 4 artilerijos pulkai ir kitos dalys ${ }^{8} .1939 \mathrm{~m}$. kariuomeneje buvo 1518 kari-

\footnotetext{
${ }^{3}$ Statkus V. Lietuvos ...P.63.

${ }^{4}$ Savanorių Žygiai. Kaunas. 1937. T.1. P.55.(pakartotas leidimas Vilnius.1991.); Statkus V Lietuvos ... P.412-413.; Surgailis G. Lietuvos kariuomenè ... P.20.

${ }^{5}$ Rukša A. Kovos dèl Lietuvos Nepriklausomybès (kovos su lenkais 1920-1923).Cleveland.1982.T.3.P419.

${ }^{6}$ Smolenski J. Walki polsko - litewskie na Suwalszczyžnie we wrzešniu 1920 r. Warszawa.1938.

${ }^{7}$ Rukša A. Kovos... P.460.

${ }^{8}$ Surgailis G. Lietuvos kariuomenè ... P.21.
} 
ninku, o $1940 \mathrm{~m}$. kovo ld. kariuomenejje tarnavo 17 generolų, 1800 karininku, 30078 puskarininkiai ir kareiviai zacija ${ }^{9}$ (iš viso 31 895). Taip pat užsimenama ir apie mobilizacines kariuomenès galimybes. Pateikiami duomenys, kad paskelbus visuotinę mobilizaciją kariuomenę planuota padidinti iki 150000 žmonių, ir turint 500000 tinkamų tarnybai vyru mobilizacinis rezervas siektu 120000 karių. Kalbama ir apie kariuomenès padidèjimą iki 85000 kariu 1939-uju rugsëji, kai buvo ivykdyta dalinė mobili-zacija ${ }^{10}$. V. Statkus taip pat pateikia nemažai ir kitu ivairių kariuomenès skaičių. Remdamasis iki II pasaulinio karo Tautu Sajungos leistu metraščiu "Armaments Year-Book", kuriame buvo skelbiama informacija apie Tautu Sajungai priklausančiu valstybiu ginkluotasias pajègas, jis nurodo $1926 \mathrm{~m}$. Lietuvos kariuomenès gyvosios jègos skaičius: karininku - 1 380, karo valdininkų - 266, liktiniu puskarininkiu - 1 922, būtinosios tarnybos puskarininkių - 3316 ir eilinių grandiniu - 14707 (iš viso 21591 karys). Nurodomas ir apytikslis Šauliu sajungos narių skaičius - 40000 zacija $^{11}$. Toliau autorius pateikia dar dvi skaičiu grupes iš vèlesnių to paties metraščio tomų: $1937 \mathrm{~m}$. kariuomeneje buvo 1550 karininku ir 21000 kareivių, iš viso 22550 karių ir 1940 m. - 1750 karininkų ir 22400 kareivių, iš viso 24150 karių. Pateikiamas ir išaugęs Šauliu sajungos skaičius - iki 55000 žmoniu zacija $^{12}$. Kitoje leidinio vietoje nurodomas dar vienas $1940 \mathrm{~m}$. Šauliu sajungos skaičius, kur teigiama, kad joje buvo 42000 rikiuotès šauliu, 15 000 moterų šaulių ir apie 5000 šaulių rèmëjų zacija ${ }^{13}$. V.Statkaus knygoje figūruoja ir jau minèti mobilizacijai tinkamų žmonių ir mobilizacijai numatytu vyru skaičiai. G.Surgailis greičiausiai remiasi V.Statkaus pateiktais duomenimis, tik V.Statkus nurodo 87000 mobilizuotu $1939 \mathrm{~m}$. vyrų skaičių zacija ${ }^{14}$. Jis taip pat pamini dar kelis skaičius, teigdamas, kad 1926 m. rudeni buvo numatyta galimybè mobilizuoti 60000 karių zacija $^{15}$ ir kad pagal 1935 metais priimtą ir vyriausybès patvirtintą kariuomenès organizaciją tuo metu taikos meto kariuomeneje buvo 1800 karininku ir 28000 kareiviu (iš viso 29800 kariu), o 1939 m. prijungus Vilniaus krašta kariuomenès skaičius bu-

\footnotetext{
${ }^{9}$ Surgailis G. Lietuvos kariuomenè ... P.28.

${ }^{10}$ Surgailis G. Lietuvos kariuomenè ... P.28-29.

${ }^{11}$ Statkus V. Lietuvos ... P. 437-438.

${ }^{12}$ Statkus V. Lietuvos... P.438.

${ }^{13}$ Statkus V. Lietuvos... P.772.

${ }^{14}$ Statkus V. Lietuvos ...P.392, 561.

${ }^{15}$ Statkus V. Lietuvos... P.560.
} 
vo padidintas iki 33000 . VStatkus dar pateikia kariuomenès žmoniu pasiskirstymą pagal ginklų rūšis, kur pėstininkai sudarè $52 \%$ bendro kariuomenès skaičiaus, artilerija $21 \%$, kavalerija $15 \%$, aviacija $6 \%$, karo technikos dalys $4 \%$ ir tarnybos $2 \%{ }^{16}$. Didesnę dali V. Statkaus pateiktų duomenų savo publikacijoje net nesistengdami ju patikrinti perpublikuoja Algimantas Kasparavičius ir Tomas Mieliauskas ${ }^{17}$. Tiesa, autoriai pateikia kelis naujus 1926 m. skaičius, paimtus iš Vyriausiojo štabo viršininko pik. Kazio Škirpos raporto krašto apsaugos ministrui. Šiais duomenimis, 1926 m. vasara, visoje Lietuvos kariuomeneje tarnavo tik 11714 karių ir buvo parengta 75000 atsarginių. Tuo metu Lietuvos kariuomenei labiausiai trūko žemesniosios grandies karo vadų: vyr.puskarininkiu - $55.3 \%$, jaun. puskarininkiu - $82.4 \%$, grandiniu $68.5 \%{ }^{18}$. Dar keletą skaičių rasime kitų istorikų bei kariuomenès tyrinètojų darbuose. Arvydas Pociūnas pateikia 1939 metu Lietuvos kariuomenės skaičių nurodydamas, kad tuo metu kariuomenejje buvo 24170 karių $^{19}$. Henry L. Gaidis pristato dar kelis bendrus kariuomenès skaičius. Jis nurodo, kad tarpukariu Lietuvos kariuomenès skaičius svyravo nuo 22 iki 28 tūkstančiu kad Šaulių sajungoje buvo 42000 vyrų, o pavojaus atveju buvo galima mobilizuoti iki 200000 kariškai parengtų vyrų ${ }^{20}$ bei nurodo kovų už Nepriklausomybę metu 1919 - $1920 \mathrm{~m}$. kariuomenejje buvus 12000 savanoriu ir bendrą kariuomenès 50000 vyru skaičių ${ }^{21}$. Tiksliausius $1920 \mathrm{~m}$. duomenis apie kariuomenès sudètị pateikia istorikas Vytautas Lesčius. Monografijoje apie Lietuvos kariuomene 1918-1920 m. kariuomenès skaičiams jis skyrè nedideli knygos skyreli. Čia autorius pateikia 1920 m. gruodžio mèn. 15 d. kariuomenès sudèties lentelę. Šiais duomenimis, kariuomenèje buvo 45314 karių (41582 kareiviai, 1123 karininkai, 416 karo valdininkai, 101 gydytojas, 16 kunigu, ir 2076 laisvai samdomi tarnautojai $)^{22}$.

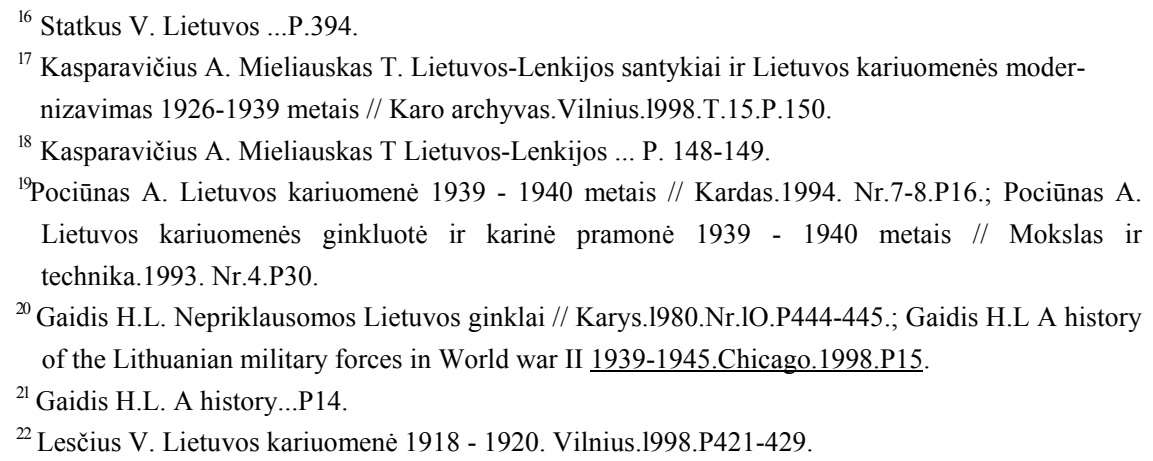


Nemažai ịvairiausių Lietuvos kariuomenès skaičiu pateikia ir mūsų kaimynai lenkai, kurie pastaraisiais metais suaktyvino Lietuvos kariuomenès istorijos tyrimus. Prieš dešimtmeti Lenkijoje buvo pakartoti Lenkijos karo atašè Lietuvoje 1938 - 1939 metais pulkininko Leono Mitkievičiaus (Leon Mitkiewicz) prisiminimai. Juose Šaulių sajungos karių skaičius pateikiamas remiantis Lenkijos kariuomenès štabo parengta medžiaga, pavadinta "Dossier Litwa": Lietuvoje esą buvę 25000 šaulių ${ }^{23}$. Atskirai pateikiamas ir $1938 \mathrm{~m}$. kovo mènesio kariuomenès bei bendras kariuomenès ir Šaulių sajungos narių skaičius: atitinkamai 2000 karininkų bei 22 000 kareivių ir $50000^{24}$ šaulių. Iš istorikų, kurie daugiausiai dèmesio skyrè Lietuvos kariuomenès tyrimams, reikia paminèti Marioną Zgurniaką (Marian Zgorniak) iš Krokuvos ir Valdemarą Rezmeri (Waldemar Rezmer) iš Torūnès. M. Zgurniakas, tyrinėdamas karinę situaciją Europoje iki II pasaulinio karo ir aptardamas Lietuvos kariuomenę, rèmėsi Vokietijos kariuomenès štabo ikikariniais šaltiniais ir, cituodamas jau minètą L. Mitkievičiu, nurodè, kad 1938 metais kariuomenejje turejo būti apie 28-30 tūkstančiu žmonių, iš jų apie 2000 karininkų. Jis nurodo, kad mobilizacijos atveju Lietuvos kariuomenè turèjo išaugti iki 100000 žmonių, bei pateikia kiek perdètą Šaulių sajungos skaičiu - 90-110 tūkstančių žmonių ${ }^{25}$. Daug daugiau duomenų apie Lietuvos kariuomenę rasime V. Rezmerio tyrimuose. Viename iš savo mokslinių straipsnių karo istorikas pateikia apytikslius 1920 metų Lietuvos kariuomenès skaičius iš prancūzų duomenų. Jie rodo, kad kariuomenejje buvo 40000 karių ir turèta galimybẻ kasmet mobilizuoti po 15000 žmonių. Greta šių pateikiami ir Lenkijos kariuomenès žvalgybos 1920 - 1921 m. periodiniai duomenys. Šiais duomenimis, Lietuvos kariuomeneje 1920 m. pavasari buvo 15000 durtuvų ir 480 kardų, $1920 \mathrm{~m}$. vasaros pradžioje - 19500 durtuvų ir 800 kardu, 1920 m. rugpjūti - 30000 durtuvų ir 500 kardug, $1920 \mathrm{~m}$. spalio $1 \mathrm{~d}$. - 40000 durtuvu ir 750 kardų, $1921 \mathrm{~m}$. sausio 15 d. - 15000 durtuvų ir 1250 kardų ir $1921 \mathrm{~m}$. liepos $1 \mathrm{~d}$ - -22000 durtuvų ir $1800 \mathrm{kardų}^{26}$. Pačioje

\footnotetext{
${ }^{23}$ Mitkiewicz L. Wspomnienia Kowienskie 1938 - 1939 (II leidimas) .Warszawa-Wroc-

law,1989.S.52. (I leidimas. London.1968.)

${ }^{24}$ Mitkiewicz L. Wspomnienia ... s.53.

${ }^{25}$ Zgorniak M. Europa w przededniu wojny (sytuacja militarna w latach 1938-1939).Krakow, 1993.S.82.

${ }^{26}$ Rezmer W. Armia Litewska w šwietle raportow oddzialu II Sztabu Generalnego wojska Polskiego (1919-1921) / Lietuvos karybos istorijos klausimai (2).Kaunas.1994.P.86-87.
} 
naujausioje studijoje, skirtoje Lietuvos karo aviacijos 1919 - 1940 m. istorijai, apžvelgdamas Lietuvos kariuomenę V. Rezmeris kartoja jau aukščiau minètus skaičius, taip pat pateikia jau V. Statkaus, J. Smolenskio, A. Pociūno aptartus. Greta jų yra dar keli nauji, neminèti duomenys. V. Rezmeris, remdamasis Vinco Vitkausko 1928 m. "Mūsu žinyne" skelbtais duomenimis $^{27}$, konstatuoja, kad nuo 1920 m. spalio iki lapkričio Lietuvos kariuomenès karių skaičius išaugo nuo 17196 iki $25409^{28}$. Autorius pateikia ir dar vieną $1939 \mathrm{~m}$. spalio pradžios Lietuvos kariuomenès skaičių. Remdamasis Leono Sabaliūno duomenimis ${ }^{29}$, $\mathrm{kad}$ dalinès mobilizacijos metu buvo pašaukta apie 10000 rezervistų, suskaičiuoja apytikrị kariuomenès skaičiu, kuris turèjo sudaryti apie 40000 žmonių $^{30}$. Greta šiu publikacijų reikia paminèti ir Andžejaus Gžyvačiaus (Andrzej Grzywacz) tekstą apie 1922 metu potencialius Lenkijos karinius priešus, kur taip pat yra ir keletas tuometinès Lenkijos kariuomenès žvalgybos surinktų duomenų apie Lietuvos kariuomenės $d y d i^{31}$. Šiame straipsnyje yra nurodyta, kad Lietuvos kariuomenëje $1922 \mathrm{~m}$. buvo 35000 kariu, kad be reguliariu pajègu ji turinti Šaulių sajungą kurioje yra apie 20000 narių, taigi Lietuvos karines pajëgas sudare apie 45000 karinès parengties žmonių $^{32}$. Taip pat reikia paminèti, kad šiuos duomenis lenkų žvalgyba gavo iš Lietuvos generolo Leono Radus-Zenkavičiaus pranešimo Maskvoje per nusiginklavimo konferenciją. Vadinasi, duomenys patikimi.

Baigiant šią skaičių apžvalgą reikia paminèti ir 1923 metų Lietuvos gyventojų surašymo duomenis. Išleistoje surašymo medžiagoje taip pat yra minimi ir keli kariuomenès skaičiai. Iš bendro suregistruotų 2028971 žmonių skaičiaus nurodant Lietuvos gyventojus pagal pragyvenimo šaltini, nurodyti 23092 Krašto apsaugos sistemoje dirbantys žmonès, 22894 vyrai ir 198 moterys $^{33}$.

\footnotetext{
${ }^{27}$ Vitkauskas V. Mūsų pèstininkai. // Mūsų žinynas,1928.T.15.P.223.

${ }^{28}$ Rezmer W. Litewskie lotnictwo wojskowe 1919 - 1940. Torun.1999.S.29.

${ }^{29}$ Sabaliūnas L. Lithuania in Crisis.Bloomington/London.1972.P.145.

${ }^{30}$ Rezmer W. Litewskie ... S.56.

${ }^{31}$ Grzywacz A. Sytuacja wojskowa potencjalnych przeciwnikow Polski w 1922 roku // Mars. Warszawa-London,1997.T.5.S.137-148.

${ }^{32}$ Grzywacz A. Sytuacja...S.141.

${ }^{33}$ Lietuvos gyventojai, 1923 m. rugsèjo 17 d. surašymo duomenys.Kaunas.1926.P.XL,222.
} 


\section{Lietuvos kariuomenès sudètis ir jos kitimas 1920 - $1927 \mathrm{~m}$.}

Peržvelgus Lietuvos kariuomenès studijas, matyti tikrai didelè gausa kuo ịvairiausių duomenų ir skaičių. Dauguma jų yra suapvalinti ir abstraktūs, kiti kiek tikslesni, bet išblaškyti, kai kurie net perdèti ir netikslūs. Kadangi iki šiol kariuomenès skaičiai atskirai nebuvo tyrinèti, o ir dèl minètu priežasčiu pamėginsime, naudodamiesi Lietuvos centriniame valstybiniame archyve saugomais I - osios Lietuvos Respublikos kariuomenès dokumentais, juos pateikti ir aptarti kiek plačiau. Daugiausiai buvo naudojamasi Krašto apsaugos ministerijos kariuomenès štabo komplektavimo ir rezervų dalies dokumentais.

Iš archyvinių dokumentų matyti, kad kariuomenès sudèties įvairūs duomenys buvo kruopščiai renkami ir periodiškai surašinejjami. Jau nuo 1920 metų pradžios duomenys buvo registruojami tam parengtose Žiniu apie kariuomenès sudèti lentelèse. Šiose lentelèse buvo fiksuojama labai smulki informacija, iš kurios galima sužinoti ne tik bendrą kariuomenès skaičių, bet ir atskirų jos sudedamujų dalių - štabų, pulkų, atskirų kuopu bei tarnybų, komendantūru - ir pačios Krašto apsaugos ministerijos atskirų padalinių sudèti. Greta žmonių skaičiaus, paprastai buvo pateikiami duomenys apie ginkluotę ir arkliu skaičių. Patys duomenys buvo registruojami savaitès intervalu ${ }^{34}$. Iš tokiu žinių, galime susidaryti pakankamai aišku kariuomenès sudèties kitimo vaizdą. Plačiau nekalbėdami apie kariuomenès kūrimosi pirmuosius metus, paminėsime keletą 1920 metų skaičiu. Sausio 24 d. kariuomenès sąrašuose buvo 28903 kariai (iš jų 27725 kareiviai, 860 karininku, 290 valdininkų ir 28 gydytojai) ${ }^{35}$. Tų pačiu metu kovo 13 d. kariuomenèje buvo 30366 kariai (28 925 kareiviai, 900 karininku, 444 valdininkai ir 97 gydytojai $)^{36}$, rugsèjo 1-8 d. - kariuomenejje buvo 27802 kariai (26 391 kareiviai, 970 karininku, 350 valdininkų ir 91 gydytojas) ${ }^{37}$. Na, o 1921 metų sausio mèn. 4 d. kariuomenès

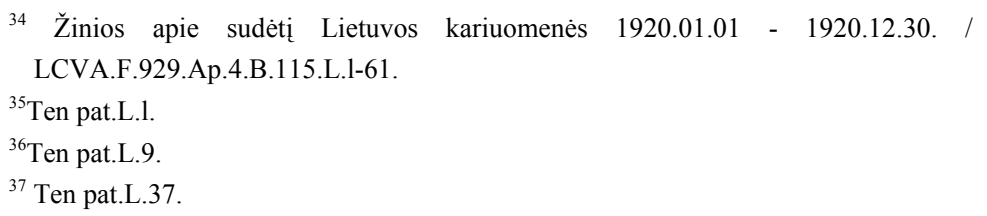


skaičius jau gerokai padidejęs. Tai sąlygojo konfliktas su lenkais. Archyviniuose dokumentuose $1921 \mathrm{~m}$. sausio pradžioje nurodomas $43996 \mathrm{ka}-$ rių skaičius (42 336 kareiviai, 1139 karininkai, 416 valdininkų ir 105 gydytojai) $^{38}$. Palyginus pateiktuosius ir V. Rezmerio publikacijoje minètus 1920 $\mathrm{m}$. Lietuvos kariuomenès duomenis, kuriuos turejo Lenkijos kariuomenès žvalgyba, galima pasakyti, kad lenkai nuo realios tiesos buvo nedaug nukrype ir apie lietuvius turejo pakankamai tikslius duomenis. Taip pat reikia paminèti, kad registruojami kariuomenès sudeties duomenys buvo ne tik perduodami vyriausiajam kariuomenès vadui, bet ir tuo metu Lietuvoje veikusiai Anglų misijai ${ }^{39}$. Reikia atkreipti dèmesi dar į vieną svarbu faktą, kad sąrašinis kariuomenès dydis skyrèsi nuo realaus. Pavyzdys dokumentuose kartu pateikti sąrašu ir iš tikrujų esančių kariuomenejje žmonių 1920 metų spalio mėn. 22 d.- lapkričio mèn. 1 d. skaičiai. Sąrašuose užregistruotas 35825 karių skaičius, tuo tarpu iš tikrujų buvo 25 148 karių $^{40}$. Taigi matome net labai ryškų skirtumą. Kol kas tokio skirtumo priežasčių nepavyko nustatyti, tai paliekama ateities tyrimams.

1928 metais kariuomenès štabe buvo atliktas kariuomenès skaičiaus žinių surašymas pradedant 1920 metų spalio mènesiu ir baigiant 1927 metu gruodžiu ${ }^{41}$. Remiantis šiuo dokumentu, yra sudarytos ir žemiau pateikiamos kariuomenès sudèties žinių atskirų metų lentelès, kur kiekvieno mènesio duomenys yra pateikti atskirai. Iš pateiktų duomenu matyti, kad nuo $1920 \mathrm{~m}$. spalio kariuomenès skaičius su nedideliais svyravimais tolygiai augo ir $1921 \mathrm{~m}$. gruodi ir $1922 \mathrm{~m}$. sausi buvo pasiekęs rekordini skaičių - atitinkamai 51123 ir 51154 (žiūrèk lenteles nr. 1-3). 1922-1924 metu laikotarpiu Lietuvos kariuomenè buvo pertvarkoma taikos meto sąlygoms, buvo išformuojami atskiri jos daliniai ir tai tiesiogiai atsiliepe kariuomenès skaičiaus kitimui. 1922 metais kariuomenès skaičius pradejjo tolygiai mažèti ir jau gruodžio mėnesi buvo daugiau kaip 20000 žmoniǔ mažesnis negu sausi bei sudare 30715 (lentelè nr.3.). Tiesa, labiausiai skaičius sumažejo $1922 \mathrm{~m}$. spalio-lapkričio mènesiais, kai, kaip matyti iš pateiktų duomenų, iš kariuomenès buvo paleista per 10000 žmonių: 42 132 registruotu karių spali iki 31114 lapkriti. Tačiau 1923 m. sausi kariuomenès skaičius vèl padidèjo. Tai yra susiję su tiesioginiu kariuome-

\footnotetext{
${ }^{38}$ Ten pat.L.61.

${ }^{39}$ Ten pat.L.1.

${ }^{40}$ Ten pat.L.45.
} 
nès dalyvavimu atsiimant Klaipėdos kraštą. Tuo metu kariuomenès skaičius vèl peršoko keturiasdešimties tūkstančiu karių ribą ir pasiekè 40502 karių skaičių (lentelè nr. 4.). Jau nuo $1923 \mathrm{~m}$. vasario kariuomenès skaičius mažėjo kiek labiau svyruodamas. Rekordiškai mažą skaičiu kariuomenė pasiekė 1924 metų lapkriti, kai joje buvo užregistruotas 13421 karys (lentelè nr.5.). Nuo 1925 m. rudens nusistovejo ir šaukimu i kariuomenę tvarka, kuri taip pat tiesiogiai turejjo įtakos kariuomenès skaičių kitimui. 1925 metais buvo net trys naujokų šaukimai - sausị, birželi ir lapkritị. Nuo 1926 m. iki 1939 m. gegužès naujokų šaukimai i kariuomenę vyko du kartus - gegužę ir lapkriti. Pati tarnyba kariuomenejje truko pusantrų metų, o kai kuriose tarnybose - 18 mėnesių. 1925 metais kariuomenès skaičius svyravo nuo 15302 iki 19627 karių (lentelè nr.6.). 1926 m. vykdant lèšų taupymo programa, kliuvo ir kariuomenei. Jos skaičius dar labiau sumažėjo ir svyravo nuo 7894 karių gegužę iki 14991 kariu gruodi (lentelè nr.7.). Po 1926 m. gruodžio 17 d. perversmo kariuomenès skaičiaus kitimas stabilizavosi ir šis skaičius pamažu pradejjo didèti - 1927 m. gruodyje po iprastinio naujoku šaukimo kariuomenejje buvo 15701 kariu. Čia reikia pasakyti, kad skaičiuojant kariuomenès sudètị būta ir netikslumų, kurie tiesiogiai veikè bendrus duomenis. Jų priežastis buvo atskirų dalinių netiksliai pildomos lentelès, dèl ko kariuomenès vadovybė įspėdavo klaidas padariusius karininkus ir reikalavo jas ištaisyti ${ }^{42}$.

Lentelè nr. 1. Lietuvos kariuomenès sudėties žinios 1920 metais $^{43}$

\begin{tabular}{|l|c|c|c|}
\hline \multicolumn{1}{|c|}{ ménuo } & X & XI & XII \\
\hline Kariuom. žmonès & & & \\
\hline karių & 31519 & 37146 & 41763 \\
\hline laisvai samdomu & 1801 & 2026 & 2119 \\
\hline IS VISO & 33320 & 39172 & 43882 \\
\hline & & & \\
\hline
\end{tabular}

${ }^{41}$ Žinios apie Lietuvos kariuomenès skaičių nuo 1920.10.01 iki 1928.01.01./LCVA. F. 929. Ap. 5. B. 286.L. 1-1 ap.

${ }^{42}$ 1926.04.28. KAM Vyriausiojo Štabo viršininko pik. 1tn. K.Škirpos raštas I Karo Apygardos viršininkui Nr. 3122 si. /LCVA. F. 929. Ap. 5. B. 218 . L. 236.

${ }^{43}$ Žinios apie Lietuvos kariuomenès skaičių nuo 1920.10.01 iki 1928.01.01./LCVA. F. 929. Ap. 5. B. 286. L. 1. 


\begin{tabular}{|c|c|c|c|c|c|c|c|c|c|c|c|c|}
\hline & $I$ & $\overline{I I}$ & III & IV & $\mathrm{V}$ & $\mathrm{VI}$ & $\overline{\text { VII }}$ & VIII & IX & $\mathrm{X}$ & $X I$ & XII \\
\hline kariu & 42583 & 42672 & 43970 & 43641 & 43192 & 43630 & 44149 & 44524 & 44473 & 43646 & 47118 & 48458 \\
\hline $\begin{array}{l}\text { laisvai } \\
\text { samdomu }\end{array}$ & 1898 & 2036 & 2082 & 2078 & 2189 & 2435 & 2431 & 2416 & 2374 & 2441 & 2667 & 2665 \\
\hline IŠ VISO & 44481 & 44708 & 46052 & 45719 & 45381 & 46065 & 46580 & 46940 & 46847 & 46087 & 49785 & 51123 \\
\hline
\end{tabular}

Lentelè nr. 3. Lietuvos kariuomenès sudèties žinios 1922 metais $^{45}$

\begin{tabular}{|c|c|c|c|c|c|c|c|c|c|c|c|c|}
\hline $\begin{array}{l}\text { Kar. } \\
\text { žmonès. }\end{array}$ & I & I I & I I I & IV & V & VI & VII & VIII & IX & X & XI & XI I \\
\hline kariu & 48049 & 46660 & 46449 & 46074 & 43653 & 40310 & 40155 & 40106 & 39809 & 39528 & 28547 & 28086 \\
\hline $\begin{array}{l}\text { laisvai } \\
\text { samdomu }\end{array}$ & 3105 & 3040 & 3080 & 2877 & 3035 & 2981 & 2987 & 2967 & 2993 & 2604 & 2567 & 2629 \\
\hline IŠ VISO & 51154 & 49700 & 49529 & 48951 & 46688 & 43291 & 43142 & 43073 & 42802 & 42132 & 31114 & 30715 \\
\hline \hline
\end{tabular}

${ }^{44}$ Ten pat.L.1.

${ }^{45}$ Ten pat.L. 1. 
Lentelè nr. 4. Lietuvos kariuomenès sudèties žinios 1923 metais $^{4}$

\begin{tabular}{|l|l|l|l|l|l|l|l|l|l|l|l|l|}
\hline $\begin{array}{l}\text { Kar. Menuo } \\
\text { žmones }\end{array}$ & I & I I & III & IV & V & VI & VII & VIII & IX & X & XI & XII \\
\hline kariu & 37760 & 31952 & 30822 & 35415 & 34958 & 32569 & 27335 & 25493 & 24118 & 21822 & 19886 & 18419 \\
\hline $\begin{array}{l}\text { laisvai } \\
\text { samdomu }\end{array}$ & 2742 & 2658 & 2436 & 2301 & 2253 & 2187 & 2019 & 4687 & 4578 & 4591 & 1565 & 1462 \\
\hline IŚ VIS0 & 40502 & 34610 & 33258 & 37716 & 37211 & 34756 & 29354 & 30180 & 28696 & 26413 & 21451 & 19881 \\
\hline
\end{tabular}

Lentelè nr. 5. Lietuvos kariuomenès sudèties žinios 1924 metais $^{4}$

\begin{tabular}{|l|l|l|l|l|l|l|l|l|l|l|l|l|}
\hline $\begin{array}{l}\text { Mar. } \\
\text { Ǩmuo }\end{array}$ & I & I I & $\mathrm{m}$ & IV & V & VI & VII & VIII & IX & X & XI & XII \\
\hline kariu & 15489 & 19498 & 19264 & 19103 & 18919 & 18726 & 18488 & 18295 & 18165 & 18019 & 12746 & 15574 \\
\hline $\begin{array}{l}\text { laisvai } \\
\text { samdomu }\end{array}$ & 884 & 763 & $\mathbf{7 4 1}$ & $\mathbf{7 1 1}$ & 682 & 678 & 672 & 666 & 663 & 660 & 675 & 666 \\
\hline IS VISO & 16373 & 20261 & 20005 & 19814 & 19601 & 19404 & 19160 & 18961 & 18828 & 18679 & 13421 & 16240 \\
\hline
\end{tabular}

${ }^{46}$ Ten pat.L.1.

${ }^{47}$ Ten pat.L. 1.

154 
Lentelè nr. 6. Lietuvos kariuomenės sudèties žinios 1925 metais $^{4}$

\begin{tabular}{|c|c|c|c|c|c|c|c|c|c|c|c|c|}
\hline $\begin{array}{l}\text { Ménuo } \\
\text { zamonès }\end{array}$ & $I$ & II & III & IV & $\mathrm{V}$ & $\mathrm{VI}$ & VII & VIII & IX & $\mathrm{X}$ & $\mathrm{XI}$ & XII \\
\hline kariu & 18958 & 18739 & 18598 & 17409 & 14999 & 17559 & 17304 & 16988 & 16853 & 13819 & 14463 & 17918 \\
\hline $\begin{array}{l}\text { laisvai } \\
\text { samdomul }\end{array}$ & 669 & 666 & 660 & 646 & 634 & 634 & 616 & 607 & 607 & 612 & 616 & 613 \\
\hline $\begin{array}{l}\text { virš tar- } \\
\text { nybiniu }\end{array}$ & - & & - & 617 & 706 & 721 & 731 & 735 & 740 & 871 & 842 & 849 \\
\hline IS VISO & 19627 & 19405 & 19258 & 18673 & 16339 & 18914 & 18651 & 18330 & 18200 & 15302 & 15921 & 19380 \\
\hline
\end{tabular}

${ }^{48}$ Ten pat.L.1. 
Lentelè nr. 7. Lietuvos kariuomenès sudèties žinios 1926 metais $^{49}$

\begin{tabular}{|c|l|l|l|l|l|l|l|l|l|l|l|l|}
\hline $\begin{array}{l}\text { Kar. } \\
\text { žmonèn }\end{array}$ & I & II & I I I & IV & V & VI & VII & VIII & IX & X & XI & XII \\
\hline kariu & 12485 & 12064 & 11784 & 11279 & 6309 & 11435 & 11063 & 10850 & 10829 & 10622 & 7532 & 13433 \\
\hline $\begin{array}{l}\text { laisvai } \\
\text { samdomu }\end{array}$ & 589 & 605 & 648 & 656 & 658 & 664 & 671 & 687 & 699 & 679 & 678 & 677 \\
\hline $\begin{array}{c}\text { virš tar- } \\
\text { nybiniu }\end{array}$ & 918 & 899 & 881 & 834 & 927 & 937 & 936 & 918 & 916 & 879 & 890 & 881 \\
\hline IS VISO & 13922 & 13568 & 13313 & 12769 & 7894 & 13036 & 12670 & 12455 & 1244 & 12180 & 9100 & 14991 \\
\hline
\end{tabular}

${ }^{49}$ Ten pat.L.1. 
Lentelè nr. 8. Lietuvos kariuomenès sudèties žinios 1927 metais $^{50}$

\begin{tabular}{|c|c|c|c|c|c|c|c|c|c|c|c|c|}
\hline ǩmonès & $I$ & II & III & IV & V & VI & VII & VIII & IX & $\mathrm{X}$ & $\mathrm{XI}$ & XII \\
\hline karius & 13213 & 13037 & 12905 & 12829 & 13008 & 14031 & 13750 & 13513 & 13331 & 12922 & 7252 & 13817 \\
\hline $\begin{array}{l}\text { laisvai } \\
\text { samdomu }\end{array}$ & 673 & 674 & 677 & 689 & 705 & 692 & 701 & 707 & 708 & 705 & 721 & 740 \\
\hline $\begin{array}{l}\text { virš tar- } \\
\text { nybinių }\end{array}$ & 829 & 809 & 812 & 789 & 863 & 847 & 853 & 840 & 838 & 836 & 888 & 920 \\
\hline kariūnu & -- & -- & -- & -- & -- & -- & -- & -- & -- & 121 & 117 & 116 \\
\hline aspirantu & - & -- & -- & t & -- & -- & -- & -- & -- & 49 & 49 & 18 \\
\hline auklètiniu & -- & -- & -- & -- & -- & -- & -- & -- & -- & 90 & 91 & 90 \\
\hline IS VISO & 14715 & 14520 & 14394 & 14307 & 14576 & 15570 & 15304 & 15060 & 14877 & 14723 & 9118 & 15701 \\
\hline
\end{tabular}

${ }^{50}$ Ten pat.L.1.

157 


\section{Lietuvos kariuomenès sudètis ir jos kitimas 1928-1939 m.}

1927 metais kariuomenès sudėties duomenims registruoti buvo pateiktos naujos spausdintos duomenu lentelès, kurių forma praktiškai liko nepakitusi iki pat Lietuvos okupacijos 1940-aisiais. Šiose naujose lentelèse buvo atskirti žmonių ir arklių bei ginklų ir kito materialiojo turto duomenys. Remiantis tų lentelių duomenimis, šiame darbe pateiktos pagal mėnesius sudarytos Lietuvos kariuomenès sudèties pradedant $1928 \mathrm{~m}$. ir baigiant 1939 m. lapkričiu žinios. 1939 m. paskutiniojo mènesio duomenų nèra dèl to, kad lentelès pasikeitè, nes rugsèjo 1 d. tarp Vokietijos ir Lenkijos prasidejo karo veiksmai ir rugsejjo $17 \mathrm{~d}$. buvo paskelbta Lietuvos kariuomenès mobilizacija.

Aptariant 1928-1939 metu kariuomenès duomenu lenteles, reikia pasakyti, kad jos daug informatyvesnès negu 1920-ujų ar kurio nors kito 1920-1927 m. laikotarpio. Jose pateikiami ne tik bendri kariuomenès sudedamuju dalių (karininku, tikrosios tarnybos kareiviu, liktinių kareivių, kariūnų, aspirantu) skaičiai ir jų pasiskirstymas pagal tarnybos vietas (štabus, pulkus, atskiras kuopas bei tarnybas, komendantūras, Krašto apsaugos ministerijos atskirus padalinius), bet ir suregistruota, kiek žmoniu yra realiai, kiek ligoninėse, komandiruotèse, atostogauja, areštinèse, kiek pabėgusių iš karinès tarnybos.

Iš lentelių matyti kelios tendencijos. Bendras kariuomenès skaičius iki 1934 m. pabaigos didèjo labai nežymiai. Ivairiai svyruodamas jis nuo 16483 karių 1928 metų sausi padidèjo iki 19784 karių 1934-ujjų gruodi (lentelès nr. 9-15). Nuosekliai daugejo karininkų, liktinių ir civilių tarnautojų: $1928 \mathrm{~m}$. sausi kariuomenèje buvo 1239 karininkai, 910 liktinių (puskarininkių ir viršilų) ir 747 civiliai tarnautojai, o 1934 m. gruodi -1 362 karininkai, 1 232 liktiniai, 1379 civiliai tarnautojai. Pradedant 1935 metais, kartu su kariuomenès modernizavimo darbais kariuomenės skaičiai dar labiau išaugo. $1935 \mathrm{~m}$. buvo atkurti 3-iasis ir 6-asis pėstininkų, 1-asis artilerijos bei 3iasis kavalerijos dragūnu pulkai, 1935-1936 m. suformuota priešlèktuvinès apsaugos rinktiné ir raitosios artilerijos grupè. Tai sąlygojo ir natūralų kariuomenès skaičiaus didèjimą. 1937 metais kariuomenèje buvo daugiau negu 26000 žmonių. Tuo pat metu ne tik ir toliau tolygiai daugejo karininkų, liktinių ir civilių tarnautojų, bet ir kariūnų bei aspirantų (lentelès nr. 17-18). 
Reikètų dar keletą žodžiu pridurti ir apie kitus skaičius, kurie nepateko i pateiktas lenteles. Ligoninèse per minimą laikotarpi paprastai būdavo nuo 10 iki 20 karininkų, kartais iki 30-36, o 1936 m. balandi -55. Kareivių ligoninėse būdavo kur kas daugiau - nuo 300 iki 500, o kartais net per 600. Paprastai kareivių ligoninèse padaugèdavo po šaukimo, kartais net visu 100, o kartais ir 200. İdomūs ir atostogu skaičiai. Daugiausia atostogaujančiu kareivių ir karininkų užfiksuota sausio mėnesį. Tai buvo tiesiogiai susiję su šv. Kalėdomis ir Naujaisiais metais. Tuo metu atostogų buvo išleidžiama nuo 1000 iki 4000 karių. Dažnai daug kareivių ir karininkų atostogų buvo paleidžiama prieš pavasario šaukimą, paprastai balandžio mènesį, ką galima būtų taip pat sieti ir su Velykų šventemis. Daug kareivių atostogų buvo paleidžiama ir kiekvienų metų rugpjūti, kas taip pat sietina su rudens šaukimo pradžia.

Duomenų sąrašuose buvo registruojami ir pabėgę iš kariuomenès kareiviai. Dažniausiai tai 1-5 kareiviai iš priskirtų eilinių ar grandinių kategorijai. Net 13 pabėgusių kareivių užfiksuota $1935 \mathrm{~m}$. pavasario šaukimo metu birželio mènesį. Pabėgusių puskarininkių pasitaikydavo retai. İdomūs duomenys apie sẻdinčius areštinėse ir kareivius, ir karininkus. Kareivių skaičius svyruoja nuo 40 iki 100, o kartais viršija ir 100, tačiau kokias nors tendencijas ižvelgti yra sunku. Karininkų areštinèse paprastai sẻdėdavo 1-2, kiek daugiau 19301932 metais. Tada šis skaičius siekdavo iki 6. Dažniausi areštinių inamiai buvo karo aviacijos, automobilių, 5ojo pėstininkų ir 1-ojo husarų pulkų karininkai. $1934 \mathrm{~m}$. liepos mėnesi užfiksuota, kad i areštinę buvo pasodinti 48 karininkai, kurie prisidejjo prie birželio 7 d. karinio pučo organizavimo. Kariuomenès sąrašuose pateikiamas ir dar vienas įdomus skaičius, vadinamuju auklètinių. Tai būdavo paaugliai berniukai, kurie gyveno kartu su kareiviais pėstininkų ir kavalerijos pulkuose. Auklètinių skaičius nebuvo traukiamas i bendrą karių skaičių. Kariuomenès daliniuose bendras jų skaičius buvo nuo 90 (1928 m.) iki 200 (1939 m.). Kiekviename dalinyje buvo 10-15 auklètinių. 
Lentelè nr. 9. Lietuvos kariuomenès sudèties žinios 1928 metais $^{51}$

\begin{tabular}{|l|l|l|l|l|l|l|l|l|l|l|l|l|}
\hline $\begin{array}{l}\text { Kar.žm. } \\
\text { Mej. }\end{array}$ & I & II & III & IV & V & VI & VII & VIII & IX & X & XI & XII \\
\hline karininku & 1239 & 1236 & 1234 & 1235 & 1226 & 1230 & 1230 & 1228 & 1224 & 1262 & 1255 & 1252 \\
\hline $\begin{array}{l}\text { kareiviu } \\
\text { tikr. } \\
\text { tarnybos }\end{array}$ & 13456 & 13264 & 13056 & 12880 & 12838 & 14297 & 14141 & 14062 & 13975 & 13907 & 8768 & 15140 \\
\hline $\begin{array}{l}\text { kareivių } \\
\text { virštar- } \\
\text { nybinių }\end{array}$ & 910 & 905 & 901 & 904 & 874 & 944 & 939 & 936 & 938 & 932 & 952 & 986 \\
\hline kariūnu & 116 & 116 & 116 & 116 & 116 & 116 & 116 & 116 & 116 & 124 & 124 & 124 \\
\hline aspirantų & 15 & 102 & 102 & 100 & 100 & 99 & 99 & 98 & 98 & 98 & -- & -- \\
\hline $\begin{array}{l}\text { civilių } \\
\text { tarnautoju }\end{array}$ & 747 & 747 & 743 & 755 & 752 & 760 & 773 & 784 & 785 & 803 & 811 & 844 \\
\hline \begin{tabular}{l} 
IŚ VISO \\
\hline
\end{tabular} & 16483 & 16370 & 16152 & 15990 & 15906 & 17446 & 17298 & 17224 & 17136 & 17126 & 11910 & 18346 \\
\hline
\end{tabular}

51 Kariuomenès žmonių ir arklių sudèties žinios 1928 metai // LCVA. F.929. Ap.5.B.286.L.5,7,9,11,14-21.

160 
Lentelè nr. 10. Lietuvos kariuomenės sudèties žinios 1929 metais $^{52}$

\begin{tabular}{|c|c|c|c|c|c|c|c|c|c|c|c|c|}
\hline & I & II & III & IV & $\mathrm{V}$ & VI & VII & \begin{tabular}{|l|} 
VIII \\
\end{tabular} & IX & $\mathrm{X}$ & $\mathrm{XI}$ & XII \\
\hline karininku & 1252 & 1252 & 1249 & 1234 & 1218 & 1216 & 1214 & 1212 & 1204 & 1203 & 1242 & 1239 \\
\hline $\begin{array}{l}\text { kareiviu } \\
\text { tikr. } \\
\text { tarnybos }\end{array}$ & 14685 & \begin{tabular}{|l|l|}
14469 \\
\end{tabular} & 14479 & 14332 & 8419 & 14090 & 13875 & \begin{tabular}{|l|}
13707 \\
\end{tabular} & 13641 & 13577 & \begin{tabular}{|l|}
7566 \\
\end{tabular} & 9678 \\
\hline $\begin{array}{l}\text { kareivių } \\
\text { virštar- } \\
\text { nybinių }\end{array}$ & 980 & 976 & 971 & 935 & 948 & 963 & 960 & 959 & 955 & 951 & 987 & 1009 \\
\hline kariūnų & 124 & 123 & 123 & 123 & 123 & 122 & 122 & 112 & 184 & 182 & 181 & 135 \\
\hline \begin{tabular}{|l|} 
aspirantų \\
\end{tabular} & -- & 93 & 92 & 91 & 91 & 91 & 91 & 86 & 85 & 85 & 85 & -- \\
\hline $\begin{array}{l}\text { civilių } \\
\text { tarnautojų }\end{array}$ & 850 & 859 & 888 & 971 & 1074 & 1159 & 1198 & 1206 & 1202 & 1199 & 1207 & 1225 \\
\hline \begin{tabular}{|l|l|} 
IŠ VISO \\
\end{tabular} & 17891 & 17772 & 17802 & 17686 & 11873 & 17641 & 17460 & 17282 & 17271 & \begin{tabular}{|l|l|}
17197 \\
\end{tabular} & \begin{tabular}{|l|l|}
11268 \\
\end{tabular} & 13286 \\
\hline
\end{tabular}

${ }^{52}$ Kariuomenès žmonių ir arklių sudėties žinios 1929 metai // LCVA. F.929.

Ap.5.B.318.L.1-4,6-8,10-14

161 
Lentelè nr. 11. Lietuvos kariuomenès sudèties žinios 1930 metais $^{53}$

\begin{tabular}{|l|l|l|l|l|l|l|l|l|l|l|l|l|}
\hline $\begin{array}{l}\text { Kar.žm. } \\
\text { Mej. }\end{array}$ & I & II & III & IV & V & VI & VII & VIII & IX & X & XI & XII \\
\hline karininku & 1236 & 1233 & 1229 & 1229 & 1220 & 1213 & 1204 & 1198 & 1187 & 1180 & 1244 & 1248 \\
\hline $\begin{array}{l}\text { kareiviu } \\
\text { tikr. } \\
\text { tarnybos }\end{array}$ & 9498 & 9384 & 9349 & 9315 & 8040 & 12995 & 12844 & 12739 & 12691 & 12425 & 7375 & 12286 \\
\hline $\begin{array}{l}\text { kareiviu } \\
\text { virštarnybi- } \\
\text { nių }\end{array}$ & 1006 & 1006 & 1007 & 999 & 1011 & 1027 & 1017 & 1015 & 1009 & 1002 & 1043 & 1031 \\
\hline kariūnu & 135 & 135 & 135 & 134 & 134 & 133 & 133 & 158 & 225 & 221 & 154 & 148 \\
\hline aspirantu & -- & 328 & 278 & 277 & 277 & 276 & 276 & 248 & 248 & 259 & -- & 322 \\
\hline $\begin{array}{l}\text { civilių } \\
\text { tarnautoju }\end{array}$ & 1229 & 1235 & 1243 & 1242 & 1229 & 1256 & 1264 & 1265 & 1263 & 1257 & 1273 & 1280 \\
\hline IŠ VISO & 13104 & 13321 & 13241 & 13196 & 11911 & 16900 & 16738 & 15425 & 16623 & 16344 & 9845 & 16315 \\
\hline
\end{tabular}

\footnotetext{
${ }^{53}$ Kariuomenès žmonių ir arklių sudèties žinios 1930 metai // LCVA. F.929. Ap.5.B.340.L.1,3-6,8-11,13-15
}

162 
Lentelè nr. 12. Lietuvos kariuomenès sudèties žinios 1931 metais $^{54}$

\begin{tabular}{|c|c|c|c|c|c|c|c|c|c|c|c|c|}
\hline & I & II & III & IV & $\mathrm{V}$ & $\mathrm{VI}$ & VII & \begin{tabular}{|l|} 
VIII \\
\end{tabular} & IX & $\mathrm{X}$ & $X I$ & XII \\
\hline karininku & 1247 & 1244 & 1243 & 1243 & 1245 & 1242 & 1240 & 1240 & 1242 & 1239 & 1315 & 1315 \\
\hline $\begin{array}{l}\text { kareiviu, } \\
\text { tikr. } \\
\text { tarnybos }\end{array}$ & 12128 & 11849 & 11768 & 11601 & 9565 & 14379 & 14234 & 14153 & 14078 & 13930 & 9262 & 14074 \\
\hline $\begin{array}{l}\text { kareiviu } \\
\text { virštarnybi- } \\
\text { nių }\end{array}$ & 1034 & 1028 & 1025 & 1018 & 1057 & 1041 & 1042 & 1044 & 1046 & 1045 & 1119 & 1108 \\
\hline kariūnų & 147 & 147 & 146 & 145 & 144 & 144 & 158 & 143 & 210 & 208 & 162 & 159 \\
\hline aspirantu. & 365 & 566 & 558 & 548 & 540 & 538 & 510 & 510 & 508 & 659 & 159 & 365 \\
\hline $\begin{array}{l}\text { civiliu } \\
\text { tarnautojų }\end{array}$ & 1235 & 1250 & 1272 & 1296 & 1355 & 1319 & 1231 & 1166 & 1179 & 1272 & 1327 & 1346 \\
\hline IS VISO & 16156 & 16084 & 16012 & 15851 & 13906 & 18663 & 18415 & 18256 & 18263 & 18353 & 13344 & 18367 \\
\hline
\end{tabular}

${ }^{54}$ Kariuomenės žmonių ir arklių sudèties žinios 1931 metai // LCVA. F.929. Ap.5.B.355.L.3,5-7,9-

$12,14,15,18,19$. 
Lentelè nr. 13. Lietuvos kariuomenès sudèties žinios 1932 metais $^{55}$

\begin{tabular}{|l|l|l|l|l|l|l|l|l|l|l|l|l|}
\hline ménuo & \multicolumn{1}{|c|}{ I } & II & III & IV & V & VI & VII & VIII & IX & X & XI & XII \\
\hline $\begin{array}{l}\text { Kariuom } \\
\text { žmonès }\end{array}$ & & & & & & & & & & & & \\
\hline karininku & 1311 & 1303 & 1302 & 1300 & 1293 & 1284 & 1292 & 1301 & 1295 & 1293 & 1367 & 1365 \\
\hline $\begin{array}{l}\text { kareiviu } \\
\text { tikr. } \\
\text { tarnybos }\end{array}$ & 13858 & 13754 & 13202 & 9403 & 9331 & 14231 & 13850 & 13714 & 13617 & 9188 & 9097 & 14133 \\
\hline $\begin{array}{l}\text { kareiviu } \\
\text { virštarnybi- } \\
\text { niu }\end{array}$ & 1105 & 1100 & 1106 & 1136 & 1126 & 1122 & 1119 & 1115 & 1112 & 1150 & 1151 & 1146 \\
\hline $\begin{array}{l}\text { kariūnu } \\
\text { aspirantu }\end{array}$ & 158 & 158 & 158 & 158 & 158 & 155 & 154 & 144 & 234 & 234 & 154 & 148 \\
\hline $\begin{array}{l}\text { civilių } \\
\text { tarnautojų }\end{array}$ & 1381 & 1369 & 1375 & 1373 & 1370 & 1378 & 1379 & 1382 & 1384 & 1391 & 1391 & 1394 \\
\hline \begin{tabular}{l} 
IÍ VISO \\
\hline
\end{tabular} & 18172 & 18036 & 17488 & 13706 & 13607 & 18496 & 18113 & 17972 & 17891 & 13497 & 13392 & 18411 \\
\hline
\end{tabular}

${ }_{55}^{55}$ Kariuomenès žmonių ir arklių sudèties žinios 1932 metai // LCVA. F.929. Ap.5.B.378.L.1,4-7,10-

12,14-17. 
Lentelè nr. 14. Lietuvos kariuomenės sudèties žinios 1933 metais $^{56}$

\begin{tabular}{|l|l|l|l|l|l|l|l|l|l|l|l|l|}
\hline $\begin{array}{l}\text { Ménuo } \\
\text { ariuom } \\
\text { žmonès }\end{array}$ & \multicolumn{1}{|c|}{ I } & II & III & IV & V & VI & VII & VIII & IX & X & XI & XII \\
\hline karininku & 1355 & 1353 & 1352 & 1348 & 1344 & 1339 & 1337 & 1334 & 1328 & 1409 & 1408 & 1407 \\
\hline $\begin{array}{l}\text { kareiviu } \\
\text { tikr. } \\
\text { tarnybos }\end{array}$ & 13813 & 13698 & 13609 & 9310 & 9170 & 14026 & 13691 & 13580 & 13481 & 9178 & 9065 & 14409 \\
\hline $\begin{array}{l}\text { kareiviu } \\
\text { virštarnybi- } \\
\text { nių }\end{array}$ & 1144 & 1139 & 1132 & 1168 & 1166 & 1161 & 1163 & 1158 & 1164 & 1187 & 1180 & 1169 \\
\hline \begin{tabular}{l} 
kariūnu \\
\hline aspirantu
\end{tabular} & 148 & 148 & 148 & 148 & 148 & 146 & 145 & 145 & 192 & 107 & 106 & 106 \\
\hline $\begin{array}{l}\text { civiliu } \\
\text { tarnautojų }\end{array}$ & 1395 & 1387 & 1386 & 1388 & 1384 & 1377 & 1378 & 1374 & 1346 & 1352 & 1345 & 1343 \\
\hline \begin{tabular}{l} 
IŠ VISO \\
\hline
\end{tabular} & 18070 & 17938 & 17839 & 13571 & 13419 & 18256 & 17918 & 17794 & 17703 & 13417 & 13288 & 18615 \\
\hline
\end{tabular}

${ }^{56}$ Kariuomenès žmonių ir arklių sudèties žinios 1933 metai // LCVA. F.929. Ap.5.B.395.L.1,3-6,8-

10,12-15. 
Lentelè nr. 15. Lietuvos kariuomenès sudèties žinios 1934 metais $^{57}$

\begin{tabular}{|c|c|c|c|c|c|c|c|c|c|c|c|c|}
\hline Mèn. & I & II & III & IV & $\mathrm{V}$ & $\mathrm{VI}$ & VII & VIII & IX & $\mathrm{X}$ & $\mathrm{XI}$ & XII \\
\hline karininku & 1404 & 1402 & 1396 & 1395 & 1395 & 1389 & 1391 & 1313 & 1310 & 1369 & 1364 & 1362 \\
\hline $\begin{array}{l}\text { kareiviu } \\
\text { tikr. } \\
\text { tarnybos }\end{array}$ & 14114 & 14013 & 13928 & 13815 & 9478 & 14544 & 14261 & 14127 & \begin{tabular}{|l|}
14031 \\
\end{tabular} & 9776 & 9617 & 15472 \\
\hline $\begin{array}{l}\text { kareiviu } \\
\text { virštarnybi- } \\
\text { nių }\end{array}$ & 1166 & 1158 & 1158 & 1155 & 1209 & 1210 & 1212 & 1213 & 1208 & 1226 & 1224 & 1232 \\
\hline kariūnu & 106 & 106 & 105 & 105 & 105 & 105 & 104 & 104 & 169 & 128 & 127 & 125 \\
\hline aspirantu & 179 & 179 & 175 & 175 & 172 & 171 & 168 & 167 & 152 & 221 & 220 & 214 \\
\hline $\begin{array}{l}\text { civiliu } \\
\text { tarnautoju }\end{array}$ & 1345 & 1350 & 1351 & 1355 & 1355 & 1350 & 1352 & 1359 & 1355 & 1350 & 1358 & 1379 \\
\hline IŠ VISO & 18314 & 18208 & 18113 & 18000 & 13714 & 18769 & 18488 & 18283 & 18225 & 14070 & 13910 & 19784 \\
\hline
\end{tabular}

${ }^{57}$ Kariuomenès žmonių ir arklių sudèties žinios 1934 metai // LCVA. F.929. Ap.5.B.412.L.2-5,711,13-15. 


\begin{tabular}{|c|c|c|c|c|c|c|c|c|c|c|c|c|}
\hline & & \multicolumn{2}{|c|}{ Lentelè nr. 16.} & \multicolumn{5}{|c|}{ Lietuvos kariuomenès sudèties žinios } & 1935 & metais $^{58}$ & & \\
\hline Mènuo & $I$ & II & III & IV & $\mathrm{V}$ & VI & VII & \begin{tabular}{|l|} 
VIII \\
\end{tabular} & IX & $\bar{X}$ & $\mathbf{X I}$ & XII \\
\hline karininku & 1355 & 1353 & 1352 & 1346 & 1346 & 1365 & 1361 & 1363 & 1358 & 1433 & 1432 & 1436 \\
\hline $\begin{array}{l}\text { kareiviu } \\
\text { tikr. } \\
\text { tarnybos }\end{array}$ & 15215 & 15156 & 15046 & 14875 & 14847 & 22717 & \begin{tabular}{|l|l|}
17988 \\
\end{tabular} & 17768 & 17669 & 17644 & 13128 & 20514 \\
\hline $\begin{array}{l}\text { kareiviu } \\
\text { virštarnybin }\end{array}$ & 1239 & 1246 & 1245 & 1243 & 1233 & 1229 & 1270 & 1272 & 1289 & 1291 & 1412 & 1463 \\
\hline kariūnų & 124 & 166 & 166 & 165 & 195 & 195 & 194 & 193 & 304 & 392 & 392 & 339 \\
\hline aspirantu & 213 & 171 & 169 & 167 & 136 & ${ }^{\mathrm{r}} 132$ & 136 & 136 & 136 & 241 & 234 & 231 \\
\hline $\begin{array}{l}\text { civilių } \\
\text { tarnautojų }\end{array}$ & 1390 & 1396 & 1397 & 1397 & 1398 & 1398 & 1417 & 1442 & 1435 & 1413 & 1434 & 1441 \\
\hline IŠ VISO & 19536 & 19488 & 19375 & $\mid 19193$ & 19155 & 27036 & 22366 & 22174 & 22191 & 22414 & 18032 & 25424 \\
\hline
\end{tabular}

${ }^{58}$ Kariuomenès žmonių ir arklių sudèties žinios 1935 metai // LCVA. F.929. Ap.5.B.457.L.25,10,12-15,17-19. 
Lentelè nr. 17. Lietuvos kariuomenès sudèties žinios 1936 metais $^{59}$

\begin{tabular}{|l|l|l|l|l|l|l|l|l|l|l|l|l|}
\hline Kar.žm. & I & II & III & IV & V & VI & VII & VIII & IX & X & XI & XII \\
\hline karininku & 1436 & 1436 & 1436 & 1428 & 1432 & 1532 & 1534 & 1532 & 1534 & 1669 & 1675 & 1674 \\
\hline $\begin{array}{l}\text { kareiviu } \\
\text { tikr. } \\
\text { tarnybos }\end{array}$ & 20445 & 20261 & 18509 & 13303 & 12582 & 19179 & 19077 & 18934 & 18857 & 14098 & 13407 & 21068 \\
\hline $\begin{array}{l}\text { kareiviu } \\
\text { virštarnybi- } \\
\text { nių }\end{array}$ & 1483 & 1484 & 1489 & 1559 & 1576 & 1593 & 1580 & 1576 & 1576 & 1612 & 1628 & 1636 \\
\hline kariūnu & 388 & 388 & 387 & 387 & 386 & 282 & 288 & 286 & 286 & 289 & 314 & 311 \\
\hline $\begin{array}{l}\text { aspirantu } \\
\text { 229 }\end{array}$ & 228 & 226 & 223 & 223 & 223 & 216 & 216 & 216 & 283 & 278 & 271 \\
\hline $\begin{array}{l}\text { civilių } \\
\text { tarnautoju }\end{array}$ & 1469 & 1471 & 1480 & 1481 & 1502 & 1512 & 1518 & 1516 & 1541 & 1538 & 1550 & 1556 \\
\hline IŠ VISO & $\mathbf{2 5 4 5 0}$ & $\mathbf{2 5 2 6 8}$ & $\mathbf{2 3 5 2 7}$ & $\mathbf{1 8 3 8 1}$ & $\mathbf{1 7 7 0 1}$ & $\mathbf{2 4 3 2 1}$ & $\mathbf{2 4 2 1 3}$ & $\mathbf{2 4 0 6 0}$ & $\mathbf{2 4 0 1 0}$ & $\mathbf{1 9 4 8 9}$ & $\mathbf{1 8 8 5 2}$ & $\mathbf{2 6 5 1 6}$ \\
\hline
\end{tabular}

${ }^{59}$ Kariuomenès žmonių ir arklių sudèties žinios 1936 metai // LCVA. F.929.

Ap.5.B.486.L.2-5,7-10,12-15. 
Lentelè nr. 18. Lietuvos kariuomenès sudèties žinios 1937 metais $^{60}$

\begin{tabular}{|l|l|l|l|l|l|l|l|l|l|l|l|l|}
\hline Kar.žm. & \multicolumn{1}{|c|}{ I } & II & III & IV & V & VI & VII & VIII & IX & X & XI & XII \\
\hline karininku & 1675 & 1677 & 1679 & 1676 & 1675 & 1674 & 1673 & 1673 & 1672 & 1664 & 1664 & 1638 \\
\hline $\begin{array}{l}\text { kareivių } \\
\text { tikr. } \\
\text { tarnybos }\end{array}$ & 20905 & 20711 & 20602 & 14353 & 14306 & 20955 & 20802 & 20625 & 20533 & 14345 & 14113 & 20099 \\
\hline $\begin{array}{l}\text { kareivių } \\
\text { virštarnybi- } \\
\text { nių }\end{array}$ & 1637 & 1633 & 1637 & 1751 & 1779 & 1808 & 1811 & 1807 & 1810 & 1858 & 1887 & 1907 \\
\hline kariūnų & 311 & 310 & 308 & 308 & 307 & 307 & 307 & 305 & 305 & 379 & 377 & 376 \\
\hline aspirantuc & 270 & 268 & 266 & 263 & 262 & 257 & 257 & 564 & 564 & 272 & 271 & 267 \\
\hline $\begin{array}{l}\text { civilių } \\
\text { tarnautojų }\end{array}$ & 1572 & 1592 & 1605 & 1613 & 1630 & 1659 & 1667 & 1673 & 1680 & 1679 & 1684 & 1655 \\
\hline IŠ VISO & $\mathbf{2 6 3 7 0}$ & $\mathbf{2 6 1 9 1}$ & $\mathbf{2 6 0 9 7}$ & $\mathbf{1 9 9 6 4}$ & $\mathbf{1 9 9 5 9}$ & $\mathbf{2 6 6 6 0}$ & $\mathbf{2 6 5 1 7}$ & $\mathbf{2 6 6 4 7}$ & $\mathbf{2 6 5 6 4}$ & $\mathbf{2 0 1 9 7}$ & $\mathbf{1 9 9 9 6}$ & $\mathbf{2 5 9 4 2}$ \\
\hline
\end{tabular}

${ }^{60}$ Kariuomenès žmonių ir arklių sudèties žinios 1937 metai // LCVA. F.929.

Ap.5.B.504.L.1, 2,4,5,7-10,12-15. 
Lentelè nr. 19. Lietuvos kariuomenės sudèties žinios 1938 metais $^{61}$

\begin{tabular}{|c|c|c|c|c|c|c|c|c|c|c|c|c|}
\hline mėnuo & $\mathrm{I}$ & II & III & IV & $\bar{V}$ & VI & VII & VIII & IX & $\bar{X}$ & $\mathrm{XI}$ & XII \\
\hline karininkų & 1670 & 1671 & 1667 & 1665 & 1661 & 1801 & 1793 & 1790 & 1787 & 1785 & 1785 & 1787 \\
\hline $\begin{array}{l}\text { kareiviu } \\
\text { tikr. } \\
\text { tarnybos } \\
\end{array}$ & 19961 & 19884 & 19781 & 19725 & 13081 & 18244 & 18115 & 17983 & 17935 & 17917 & \begin{tabular}{|l|}
11909 \\
\end{tabular} & 18760 \\
\hline $\begin{array}{l}\text { kareivių } \\
\text { virštarnybi- } \\
\text { nių }\end{array}$ & 1910 & 1916 & 1923 & 1918 & 2000 & 1999 & 1997 & 1992 & 1988 & 1947 & 1969 & 1988 \\
\hline kariūnų & 350 & 350 & 350 & 347 & 346 & 201 & 201 & 201 & 199 & 267 & 268 & 268 \\
\hline aspirantu & 266 & 266 & 262 & 260 & 255 & 251 & 251 & 562 & 561 & 287 & 276 & 273 \\
\hline $\begin{array}{l}\text { civilių } \\
\text { tarnautoju }\end{array}$ & 1666 & 1671 & 1672 & 1690 & 1704 & 1711 & 1724 & 1717 & 1719 & 1722 & 1731 & 1746 \\
\hline IŠ VISO & 25823 & 25758 & 25655 & 25605 & 19047 & 24207 & 24081 & 24245 & 24189 & 23925 & 17938 & 24822 \\
\hline
\end{tabular}

${ }^{61}$ Kariuomenès žmonių ir arklių sudèties žinios 1938 metai // LCVA.

F.929. Ap.5.B.527.L.1,3-6,8-11, 13-15. 
Lentelè nr. 20. Lietuvos kariuomenès sudèties žinios 1939 metais $^{62}$

\begin{tabular}{|c|c|c|c|c|c|c|c|c|c|c|c|c|}
\hline mènuo & $\mathbf{I}$ & II & III & IV & $\mathrm{V}$ & VI & VII & VIII & IX & $\mathrm{X}$ & $\mathrm{XI}$ & XII \\
\hline karininku & 1785 & 1783 & 1781 & 1777 & 1768 & 1762 & 1760 & 1747 & 1749 & 1839 & 1880 & $\mathbf{X}$ \\
\hline $\begin{array}{l}\text { kareiviu } \\
\text { tikr. } \\
\text { tarnybos }\end{array}$ & 18638 & 18541 & 18432 & 17501 & 17469 & 22216 & 16339 & 16114 & 16004 & 15601 & 16474 & $\mathbf{X}$ \\
\hline $\begin{array}{l}\text { kareivių } \\
\text { virštarnybi- } \\
\text { nių }\end{array}$ & 1982 & 1989 & 1987 & 1977 & 1971 & 1960 & 2080 & 2079 & 2084 & 2040 & 2093 & $\mathbf{X}$ \\
\hline kariūnų & 267 & 267 & 266 & 266 & 266 & 266 & 266 & 266 & 266 & 152 & 152 & $\mathbf{X}$ \\
\hline aspirantų & 270 & 268 & 266 & 259 & 254 & 250 & 250 & 600 & 600 & 352 & 350 & $\mathbf{X}$ \\
\hline $\begin{array}{l}\text { civilių } \\
\text { tarnautojų }\end{array}$ & 1748 & 1769 & \begin{tabular}{|l|}
1797 \\
\end{tabular} & \begin{tabular}{|l|}
1797 \\
\end{tabular} & 1781 & \begin{tabular}{|l}
1785 \\
\end{tabular} & \begin{tabular}{|l|}
1795 \\
\end{tabular} & \begin{tabular}{|l|}
1797 \\
\end{tabular} & 1805 & 1746 & \begin{tabular}{|l|}
1801 \\
\end{tabular} & $\mathbf{x}$ \\
\hline \begin{tabular}{|l} 
IŠ VISO \\
\end{tabular} & 24690 & 24617 & 24529 & 23577 & 23509 & 28239 & 22490 & 22603 & 22508 & 21730 & 22750 & $\mathrm{X}$ \\
\hline
\end{tabular}

${ }^{62}$ Kariuomenès žmonių ir arklių sudèties žinios 1928 metai // LCVA. F.929. Ap.5.B.564.L.1,3$6,8-11,13,14$.

171 
1939 m. rugsejjo 1 d. prasidejęs tarp Lenkijos ir Vokietijos karas Lietuvos kariuomenès skaičius pakeitè radikaliai. 1939 m. rugsèjo 17 d. Lietuvoje buvo paskelbta mobilizacija. Karių skaičius pradejo labai didèti. Archyviniuose dokumentuose pavyko rasti tikslius to meto karių skaičius. Iki rugsèjo $30 \mathrm{~d}$. bendras kadrinių ir mobilizuotų karių skaičius buvo 89470 ( iš jų 3292 karininkų ir 86178 kareivių) ${ }^{63}$. Mobilizacijos metu j kariuomenę pateko daugiau kaip 1600 karininkų ir daugiau kaip 62600 karių. Taip pat pavyko rasti ir dar vieną įdomų kariuomenès sudèties skaičių - apie tikrają padèt\} prieš mobilizacinių tvarkaraščiu Nr. 11 ir Nr.12 paskelbimą 1939 m. rugsẻjo 5 d. Šiais duomenimis, būtinosios tarnybos karininkų buvo 1 351, kareivių -17181, pašauktu iprastinių pratimu - 178 karininkai ir 8347 kareiviai bei pašauktu ypatingų pratimų - 217 karininkų ir 10005 kareiviai, kas sudare bendrą 37027 skaičių $^{64}$. Iš šių duomenų matyti, kad dar iki mobilizacijos paskelbimo kariuomenès skaičius buvo gerokai išaugęs.

Vèlesni Lietuvos kariuomenès skaičiai bus ištirti ateityje, nustatant tolesni kariuomenès sudèties pasikeitimą iki pat Lietuvos sovietinès okupacijos pradžios $1940 \mathrm{~m}$. birželį bei jai prasidèjus.

\section{Kariuomenès tautinè ir religinè sudètis. Bendrosios tendencijos}

Tyrinėdami įvairius tarpukario Lietuvos Respublikos kariuomenės skaičius, suvokiame, kad po jais slypi ir tautybių bei religijų duomenys. Todèl dažnai savęs klausiame: kokie buvo tie žmonès, kiek jų buvo, kokios buvo tautybių ir religijų proporcijos ir kt. Toks kariuomenès tyrimų aspektas reikalingas ne tik siekiant turèti išsamesnę statistika, bet ir sudaro sąlygas geriau suvokti visuomenès raidos procesus.

Tarpukario Lietuvos Respublikos kariuomené tautybių ir religijų atžvilgiu buvo tokia pat marga kaip ir visuomenè. Iš 1923 metų Lietuvos gyventojų surašymo duomenų turime aiškų gyventojų pasiskirstymo pagal tauty-

\footnotetext{
${ }^{63}$ 1939. Rugsèjis. Kariuomenès sudèties žinios mobilizaciją i̇ykdžius/LCVA. F. 929. Ap.5. B. 565.

L. 223.

${ }^{64}$ 1939.09.05. Kariuomenès kautynių dalių sudeties žinios/LCVA. F. 929. Ap. 5.B.565. L. 62.
} 
bes ir religijas vaizdą. Lietuvoje buvo užregistruotos 26 tautos. Lietuviai sudarè 83,88 \% (1 701863 žmonès) visu Lietuvos piliečių (išviso Lietuvos piliečių buvo 2021 792), antri buvo žydai - 7,58 \% (153 743), treti lenkai - 3,23 \% (65 599), ketvirti rusai - 2,49 \% (50 460), penkti vokiečiai - 1,44 \% (29 231), šešti latviai - 0,73\% (14 $883)$, septinti gudai - 0,22 \% (4 421), aštunti totoriai - 0,06\% $(973)^{65}$. Kitų tautybiu piliečiu skaičius buvo labai nedidelis. Kiek kitoks buvo Lietuvos gyventojų pasiskirstymas pagal tikybas, kurių užregistruota 30. Daugumą sudare katalikai - 85,72\% (1 739 393) bendro Lietuvos gyventojų skaičiaus (2 028 971), antri izraelitai -7,65 \% (155 125), treti liuteronai - 3,28 \% (66 578), ketvirti sentikiai -1,59\% (32 149), penkti stačiatikiai - 1,13\% (22

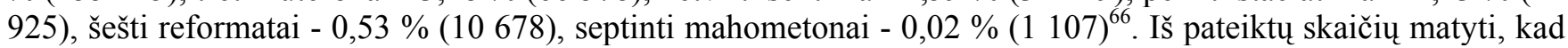
tautybių ir religijų skaičiai iš esmès sutapo. Atskirų tautybių su nedidelèmis išimtimis skaičiai praktiškai atitiko ir tam tikros religijos skaičius. Lietuviai ir lenkai buvo katalikai, žydai - izraelitai, rusai su gudais -sentikiai ir stačiatikiai, vokiečiai su latviais - liuteronai ir reformatai, totoriai - mahometonai. Kariuomenès kontingento pasiskirstymo pagal tautybes ir religijas tendencijos panašios.

Dar XX a. trečiame dešimtmetyje Vytautas Steponaitis „Mūsų žinyne" gana plačiai analizavo šaukiamų kariuomenèn naujokų išsilavinimą ir mokymą, kartu pateikdamas ir išsamius duomenis apie jų tautybes. Iš pateiktų straipsniuose duomenų sudaryta lentelè nr. 21, kurioje matyti tautybių proporcijos ir skaičių kitimo tendencijos. Tai palyginus su surašymo duomenimis, akivaizdu, kad lietuvių kariuomenèje tarnavo 3-4 procentais daugiau negu bendras tautybių vidurkis. Žydų tautybès karių vidutiniškai buvo 2 procentais mažiau negu bendras vidurkis. Mažesnis buvo ir lenkų procentas, rusų procentas beveik atitiko vidurki, o vokiečių buvo šiek tiek didesnis.

Kariuomenès štabas žinias apie kariuomenès sudėti pagal tautybes ir religijas rinko per visą Lietuvos valstybės nepriklausomybės laikotarpi. Remiantis šiais duomenimis, sudaryta duomenų lentelè nr. 22, apimanti laikotarpi nuo 1928 iki 1934 metų. Iš šių duomenų matyti, kad lietuvių kareivių skaičius padidejjo dar 2 procentais, palyginti su bendru surašymo vidurkiu. Žydų skaičius, sumažėjęs apie pusę procento, buvo stabilus,

\footnotetext{
${ }^{65}$ Lietuvos gyventojai, 1923 m. rugsèjo 17 d. surašymo duomenys. Kaunas. 1926. P. XXXVI.

${ }^{66}$ Lietuvos gyventojai, 1923 m.... P. XL.
} 
Lentelė nr.21. Procentinis Lietuvos kariuomenės naujokų pasiskirstymas pagal tautybes 1921-1926 m. laikotarpiu ${ }^{67}$

\begin{tabular}{|c|c|c|c|c|c|c|}
\hline tautybe & $1921 \mathrm{~m}$. & $1922 \mathrm{~m}$. & $1923 \mathrm{~m}$. & $1924 \mathrm{~m}$. & $1925 \mathrm{~m}$. & $1926 \mathrm{~m}$. \\
\hline Lietuviu & 86.74 & 85,49 & 86.02 & 89.31 & 87.27 & 87.60 \\
\hline Žydu & 5,40 & 7,68 & 7,12 & 4,47 & 5.01 & 5.62 \\
\hline Lenku & 3.43 & 2.35 & 1,82 & 0,95 & 2.04 & 1.85 \\
\hline Rusu & & 2.77 & 2.56 & 2.15 & 3.24 & 3.06 \\
\hline Vokiečių & & 1.21 & 2.12 & 2,64 & 2.07 & 1.60 \\
\hline Latviu & & 0.26 & 0.24 & 0.33 & 0.27 & 0.22 \\
\hline Gudų & & 0.19 & 0,10 & 0,15 & 0,06 & 0,02 \\
\hline Totoriu & & & & & 0,04 & 0.03 \\
\hline Čigonu & & & 0.01 & & & \\
\hline Karaimu & & & 0,01 & & & \\
\hline Kitu & 4,43 & - & - & 一 & 一 & - \\
\hline
\end{tabular}

${ }^{67}$ Steponaitis V. Naujokų išsilavinimas (1921-1924 met.)./Mūsųžinynas.1926.T.11.Nr.33.E358.;

Steponaitis V. Naujokų išsilavinimas (1925-26 met.)./Mūsų žinynas. 1927.T.13.Nr.37.P.2. 
žymiai sumažèjo kariuomenèje lenkų, o rusų, vokiečių ir latvių skaičius liko beveik nepakitęs. Truputi sumažèjo gudų.

Lentelè nr. 22. Procentinis Lietuvos kariuomenės kareivių pasiskirstymas pagal tautybes 1928 -1934 m. laikotarpiu ${ }^{68}$

\begin{tabular}{|c|c|c|c|c|c|c|c|}
\hline$\frac{\text { Metai }}{\text { tautybé }}$ & $1928 \mathrm{~m}$ & $1929 \mathrm{~m}$ & $1930 \mathrm{~m}$ & $1931 \mathrm{~m}$ & $1932 \mathrm{ra}$ & $1933 \mathrm{~m}$ & $1934 \mathrm{~m}$ \\
\hline lietuvlų & 91,69 & 90,77 & 9075 & 90,72 & 8923 & 89,41 & 89,67 \\
\hline Žydu & 4,10 & 4,31 & 5,34 & 4,39 & 4,55 & 436 & $42 !$ \\
\hline Lenku & 039 & 0,58 & 0,21 & 0,34 & 0,38 & 0,43 & 021 \\
\hline Rusų & 231 & 2,56 & 2,56 & 2,43 & 2,70 & 2,83 & 2,61 \\
\hline Vokiečių & 1,16 & 1,50 & 0,88 & 1,84 & 2,69 & 2,59 & $2, \ll$ \\
\hline Latvių & 0,26 & 0,18 & 0,19 & 0,20 & 0,37 & 033 & 0,45 \\
\hline Gudų & 0,02 & 0,05 & 0,02 & 0,02 & 0,01 & 0,02 & 0,01 \\
\hline kitų & 0,07 & 0,05 & 0,04 & 0,06 & 0,07 & 0,03 & 0,05 \\
\hline
\end{tabular}

Kiek kitokie buvo karininku korpuso duomenys. Kaip pavyzdi galima pateikti 1925 ir 1934 metu skaičius ir juos palyginti. 1925 rugsejo $18 \mathrm{~d}$. iš 1260 karininkų lietuvių tautybès buvo $95 \%(1197$ karininkai), gudu - 1,5\% (18), rusų - 1,2 \% (15), vokiečių - 1,1\% (14), latvių - 0,3 \% (4), žydų - 0,3\% (4), ukrainiečiu - 0,3\% (4) ir visų kitų - 0,3\% (4) ${ }^{69} .1934$ m. gruodžio 31 d. duomenimis, iš 1301 karininko lietuvių tautybès buvo 98,54\% (1 282 karininkai), rusu - 0,62\% (8), gudu - 0,30\% (4), vokiečiu - 0,08 $\%$ (1), latvių - $0,08 \%(1)$, žydų $0,08 \%(1)$, lenku - nè vieno, visų kitu - $0,30 \%(4)^{70}$. Akivaizdu, kad per dešimtmeti Lietuvos kariuomenès karininkų korpusas tapo daug lietuviškesnis. To negalima pasakyti apie kareiviu korpusa, kur kariai pagal tautybes praktiškai buvo pasiskirstę atitinkamai pagal esamas valstybès tautinès sudèties proporcijas.

Aptariant kariu pasiskirstymą pagal tikybas, reikia pažymėti, kad šia prasme pasikeitimų būta daug mažiau. Duomenu proporcijos praktiš-

\footnotetext{
${ }^{68}$ Kareivių sudètis tautybėmis 1928-1934 m./LCVA. F. 929. Ap. 4. B. 691. L. 14,18,21,23, 24, 25,30, 31.

${ }^{69} 1925.09 .18$. Žinios apie karininkus, karo gydytojus, karo valdininkus, kunigus ir laisvai samdomus karininku vietose tautybėmis / LCVA.F. 929. Ap. 4. B. 691. L. 17.

${ }^{70}$ 1934.12.31. Žinios karininkų ir civilių tarnautojų tautybėmis ir tikybomis./LCVA. F. 929. Ap. 4. B. 691. L. 31.
} 
kai atitiko 1923 m. surašymo duomenų bendras Lietuvos proporcijas. Kaip pavyzdi galima pateikti 1928, 1931 ir 1934 m. kareivių procentini pasiskirstymą pagal tautybes (žr. lentelę nr. 23).

Lentelẻ nr. 23. Procentinis kareivių pasiskirstymas pagal tikybas 1928-1934 $\mathrm{m}^{71}$.

\begin{tabular}{|l|r|r|r|}
\hline \multicolumn{1}{|c|}{ tikybos / metai } & $1928 \mathrm{~m}$. & $1931 \mathrm{~m}$. & $1934 \mathrm{~m}$. \\
\hline KatalikiL & 89.33 & 87.56 & 85.92 \\
\hline Liuteronu & 3.10 & 4.84 & 6.39 \\
\hline Izraelitu & 4.12 & 4.39 & 4.24 \\
\hline Sentikiu & 1.60 & 1.59 & 1.80 \\
\hline Stačiatildii & 1.12 & 1.07 & 1.09 \\
\hline Reformatu & 0.65 & 0.47 & 0.43 \\
\hline Visujahi & 0.08 & 0.08 & 0.13 \\
\hline
\end{tabular}

Karininku pasiskirstymas pagal tikybą atitiko tautini pasiskirstymą. Kaip pavyzdi galima pateikti 1934 metų duomenis: iš 1301 karininko katalikų buvo 91,93\% (1196), liuteronų - 3,3\% (43), stačiatikių - 2,15\% (28), reformatų - 2,07\% (27), sentikių - 0,08\% (1), izraelitų - 0,08\% (1) ir visų kitu - 0,39\% (5) $)^{72}$. Iš šių skaičių matyti, kad tam tikras procentas lietuvių karininkų buvo liuteronų tikèjimo.

Pažymètina, kad tokios pat karių ir karininkų pasiskirstymo tendencijos buvo ir daliniuose. Kai kurie iš jų buvo visu šimtu procentų lietuviški. Pavyzdžiui, toks faktas užfiksuotas 1932 metais vasario mènesị Kauno miesto komendantūroje, Vytauto Didžiojo kuopoje bei Karo mokykloje ${ }^{73}$.

Iš tarpukario Lietuvos Respublikos kariuomenès istoriografijos apžvalgos paaiškèja, kad iki šiol mokslininkų tyrimuose nebuvo plačiau operuojama tikslesniais kariuomenès skaičiais, pateikiami tik atskiri ir dažniausiai suapvalinti duomenys.

\footnotetext{
${ }^{71}$ Žinios apie kareivių sudètį tikybomis 1928-1934/LCVA. F. 929. Ap.4. B. 691. L. 21, 30, 34.

${ }^{72}$ 1934.12.31. Žinios karininkų ir civilių tarnautojų tautybèmis ir tikybomis./LCVA. F. 929. Ap. 4. B. 691. L. 32.

${ }^{73}$ 1932.vasaris. Žinios apie kariuomenès dalių kareivių ir karininkų pasiskirstymą tautybèmis ir tikybomis / LCVA. F. 929. Ap. 5. B. 544. L. 3-72.
} 
Iš Lietuvos kariuomenès sudėties kitimo nuo 1920 iki 1939 metų žiemos aiškiai matyti, kad dauguma skaičių priklausė nuo valstybejje vykusiu procesų, kuriuos veikè ir pati kariuomenè. $1921 \mathrm{~m}$. baigiantis kovoms už valstybingumo išsaugojimą, kariuomenès skaičius buvo pasiekęs ir peržengęs 50000 karių ribą. Vèliau prasidejjo kariuomenès mažẻjimo procesas. $1923 \mathrm{~m}$. sausi Klaipèdos krašto išlaisvinimo metu jis buvo dar kartą šoktelèjęs iki 40 000, $1924 \mathrm{~m}$. lapkriti pasiekè 13000 karių. Trečiajame dešimtmetyje, 1925 metais, kariuomenès dydis svyravo tarp 16-18 tūkstančių karių, 1926 m. vykdant vyriausybès lèšų taupymo programą sumažèjo iki 12000 karių, o po gruodžio 17 d. perversmo vẻl padidèjo ir $1927 \mathrm{~m}$. sudare 14-15 tūkstančiu karių. 1928 m. išaugo iki 16-18 tūkstančių ir iki 1935 metų pradžios nežymiai kisdamas laikèsi 18000 karių skaičius, kol buvo pradètas intensyvus kariuomenès modernizavimas, sąlygojęs ir žymesni karių skaičiaus augimą. Šiuo paskutiniuoju laikotarpiu kariuomenė išaugo iki 23-26 tūkstančių karių. To meto sąlygomis toks skaičius buvo optimalus. 1939 metų rugsèji tarp Lenkijos ir Vokietijos kilęs karas sąlygojo ir Lietuvos kariuomenès skaičiaus didejimą: paskelbiama mobilizacija ir kariuomenejje žmonių padidejja iki 89470.

Apie kariuomenès sudètị pagal tautybes ir tikybas reikia pasakyti, kad bendros tendencijos praktiškai atitiko 1923 metu gyventojų surašymo duomenis, tačiau karininkų korpusas ketvirtajame dešimtmetyje tapo beveik visu šimtu procentų lietuviškas, ką galima būtų paaiškinti kaip tautinès politikos, prasidèjusios 1926 metų gruodžio 17 dieną atejus i̇ valdžią tautininkams, rezultatą.

Taip pat reikia pažymèti, kad tai negalutinis tyrimu rezultatas, ateityje galima tikètis naujų duomenu bei papildymų. 


\section{Résumé}

\section{Effectif de l'armée lituanienne de 1920 q 1939, Jonas Vaicenonis (Université Vytautas le Grand)}

Une fois l'historiographie de la première république lituanienne examinée, il devient évident que jusqu'q présent les recherches scientifiques ne présentaient pas des chiffres trcs précis concernant l'armée, mais souvent fournissaient uniquement des données hors de leur contexte et le plus souvent aux résultats arrondis. Cette étude est donc une tentative de combler le manque dans ce domaine. Dans cette article sont présentées les données de composition de l'armée lituanienne, en fournissant les données année par année et pour chaque mois de l'année, en essayant de d'examiner les événements et les processus qui ont fait varier d'une manière ou d'une autre les effectifs de l'armée.

En 1921, 3 la fin des combats pour la protection de l'état, les effectifs de l'armée avaient atteint et dépassé la barre des 50 000. Le processus de réduction des effectifs de l'armée ayant commencé, l'importance de l'armée diminua peu q peu pour atteindre en novembre 1924 la limite de 13000 soldats , apres avoir fait un saut jusqu'q 40000 soldats au moment de la libération de Klaipeda en janvier 1923. $\mathrm{Au}$ troisième trimestre 1925 l'armée comportait entre 16000 et 18000 soldats. En 1926, ce nombre chuta

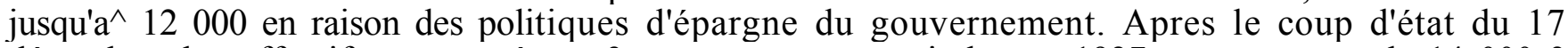
décembre, les effectifs augmentèrent 3 nouveau pour atteindre en 1927 une moyenne de 140003 15000 soldats. En 1928 ce chiffre atteint le nombre de 16000318000 et en variant de manière imperceptible, les effectifs restèrent les mzmes jusqu'au début de l'année 1935, quand furent commencés la modernisation intense de l'armée, conditionnant l'augmentation considérable des effectifs. Pendant cette dernière période, ils atteignirent le nombre de 23000326000 soldats, chiffre optimal en tenant compte des conditions existantes. Le début de la guerre entre la Pologne et l'Allemagne en août 1939 et la déclaration de mobilisation fut la raison de l'augmentation des effectifs. Le nombre des recrues augmenta jusqu'3 89470.

Dans cet article sont également présentés les tendances de com- 
position religieuse et nationale de l'armée. En s'appuyant sur ces documents, il est possible d'affirmer que la composition nationale de l'armée correspondait pratiquement a la répartition nationale de la population civile. Dans les années trente l'armée était quasiment composée $3100 \%$ de Lituaniens. Ce fait peut ztre expliqué comme la conséquence de la politique nationaliste du parti nationaliste arrivé au pouvoir après le coup d'état du 17 décembre 1926.

\section{Jonas Vaicenonis Numbers of the Lithuanian army 1920 - 1939}

Now discussing the historiography of The First Lithuanian Republic is clear, that up to now in scientific researches wasn't widely used more exact numbers of army, to present only separate and frequently round facts. This research is the attempt to fill up exist a breach of facts. In the article are presenting facts of personnel of the Lithuanian army at $1920-1939$, presenting yearly tables with facts of each month, trying to discuss the events and processes which in one way or in other influence changes of army's numbers.

In 1921 at the end of the struggle for preservation of self-dependence, number of the army was reach and overstep limit of 50000 soldiers. Later when begin the process of the decrease army, number of army gradually decrease. In January of 1923, at moment when Kaipeda land was liberated, number of army once again increase and reached 40 000. At November of 1924 number of army was 13 000. In third decen-nium of XX century, at 1925 number of army fluctuation from 16 to 18 thousands soldiers, but at 1926 accomplishing the programme of means saving of Government, number of soldiers decrease to 12000 . After December $17^{\text {th }}$, 1926 military coup d'etat he again increase and in 1927 have 14-15 thousand soldiers average. In 1928 number of army grow till 16-18 thousand, and this 18000 number standing till the beginning of 1935, when was beginning process of army modernisation, which condition distinct growing number of soldiers. In this period number of army grow till 23 - 26 thousand soldiers and was optimum for this period conditions. When begin war between Poland and German at September 1939, condition also increasing number of the Lithuanian army, which reason was mobilisation. In this moment number of army increase to 89470 .

In this article also are presenting general tendentious of national and 
religious of army personnel. Supporting of this facts we could to confirm, that national personnel of army practically corresponded distribution of population by nationality's. Only corps of officers at fourth decennium of XX century was practically at $100 \%$ Lithuanian, what we could explain by politic of Nationalists which comes to power after December $17^{\text {th }}, 1926$. 